\title{
SEASONAL EMPLOYMENT IN TOURISM ORGANIZATIONS AS A CHALLENGE FOR HUMAN RESOURCE MANAGEMENT
}

\section{Zijada Rahimić \\ Kristina Črnjar Vedrana Čikeš}

https://doi.org/10.20867/tosee.05.55

\begin{abstract}
Purpose - The purpose of this paper is to investigate the impact of seasonal employment on the policies and practices of human resource management (HRM) in tourist organizations. The framework for HR policies and practices is based on an organization's chosen business strategy, and its acceptance of the industry's seasonal nature and a dichotomous business type or its preference to run a non-seasonal business. This paper aims to analyze the differences, in carrying out specific human resource management activities, between organizations that "embrace" seasonality and dichotomous business management and those that "challenge" seasonality and prefer continuous business management.

Methodology - As a methodological framework for analyzing human resource management activities in tourism, a continuum is used, ranging from "embracing" to "challenging" seasonality. In this manner, the strategic context of HRM is taken into account and additionally vertical and horizontal alignments are explained. Seasonal employment in the EU tourism sector is analyzed and HRM trends and processes are identified and explained.

Findings - The paper presents the possibilities and limitations as well as the effects of applying various human resource management activities, depending on the chosen seasonal employment approach in the tourism sector. The results of secondary data analysis on the type and length of work engagement in the field of tourism in the EU indicate a preferred approach to seasonality. At the same time, they can serve as a basis for discussing desirable and necessary HRM policies and practices.

Contribution - The paper's contribution is reflected in emphasizing the importance of aligning HRM policies and practices with the specific features of the tourism industry, the specific features of the chosen business strategy, and the seasonal way of doing business. Research results indicate that the "war for seasonal workers" began long ago and that tourism organizations can ensure longterm sustainable success and competitive positioning only if they come up with more attractive measures to win and retain skilled and capable employees.
\end{abstract}

Keywords seasonality, tourism employment, human resource activity, temporary workers, strategic approach

\section{INTRODUCTION}

Seasonality has long been recognized as one of the most evident and significant characteristics of tourism, which is to some extent experienced by virtually every tourist destination in the world. As seasonality is reflected in the variations of tourist demand and hence labor demand, this phenomenon poses a particular challenge for human resource management in tourism organizations. Bearing in mind the strategic role and 
ToSEE - Tourism in Southern and Eastern Europe, Vol. 5, pp. 607-620, 2019

Z. Rahimić, K. Črnjar, V. Čikeš: SEASONAL EMPLOYMENT IN TOURISM ORGANIZATIONS AS A ...

importance of HRM in achieving the long-term sustainable success of an organization in today's rather dynamic and turbulent business environment, challenges are reflected in aligning HRM policies and practices with the strategic commitment of the organization. Designing and implementing all HRM activities should focus on the implementation of the formulated overall business strategy. That means that all HRM activities should reflect the organization's business strategy, i.e. whether it accepts the seasonal nature of the tourism industry or seeks to extend the season and keep on doing business throughout the year.

Seasonality is recognized as a factor influencing almost all aspects of business operations in companies working in tourism. For HRM it creates a cyclical employment environment requiring extraordinary resources devoted to processes (recruitment, selection, training, retention of staff etc.) (Jolliffe \& Farnwsworth 2003).

\section{SEASONALITY IN TOURISM EMPLOYMENT}

Seasonality is one of the most dominant yet least studied features of tourism. Tourism seasonality is a temporal imbalance in the phenomenon of tourism, which may be expressed in terms of dimensions of such elements as numbers of visitors, expenditure of visitors, traffic on highways and other forms of transportation, employment, and admissions to attractions etc. (Butler 2001). This means that seasonality affects all activities in the field of tourism.

Seasonality in tourism is not unique to a particular destination or country, but appears in almost all destinations and countries around the world. Almost all tourism companies and regions have been affected by seasonality to a lesser or greater extent. In a given period some destinations have more visitors and tourists than they can accept, while offseason capacities remain unused. To respond timely and adequately to seasonal oscillations in demand, tourism organizations need to know and track the causes of seasonality.

In the literature, several attempts have been made to understand and classify the causes of seasonality in tourism. Bar-On's study (1975) "Seasonality in Tourism: A Guide to the Analysis of Seasonality and Trends for Policy Making" is considered one of the first academic studies on seasonality. Most authors emphasize the natural and institutionalized types of tourist seasonality (Baum \& Lundtrop 2001, Koenig \& Bischoff 2005, Cuccia \& Rizzo 2011, Karamustafa \& Ulama 2010):

- Natural seasonality is linked to annual seasons, i.e. to the regular and periodic changes of the natural climate in a particular destination. Destinations with a warm and cold climate are exposed to seasonal changes that affect activities offered to tourists. Natural factors can make a destination unattractive in one part of the year but become an attraction and attract demand in the other part of the year. It is important to emphasize that natural seasonality could change due to climate change, impacting tourism in affected areas. 
ToSEE - Tourism in Southern and Eastern Europe, Vol. 5, pp. 607-620, 2019

Z. Rahimić, K. Črnjar, V. Čikeš: SEASONAL EMPLOYMENT IN TOURISM ORGANIZATIONS AS A ...

- Institutionalized seasonality is caused by human activity on social, ethnic, organizational, religious and other grounds. Unlike natural seasonality, the dates of institutionalized seasonality can be more accurately determined, as they usually follow school holidays, state holidays, religious events, festivals, etc.

Although natural and institutional factors are generally recognized as two major causes of seasonal tourism, many authors have given a more detailed classification of causes such as sociological and economic causes, social pressure and fashion, and sporting seasons (Young Chung 2009).

Seasonality is a measurable feature of tourism because it has great economic importance and can be expressed by quantitative indicators such as the number of visitors, visitor expenditure and attraction visitation rates. Different methods have been used to measure seasonality such as Seasonality Range, Seasonality Ratio and the Coefficient of Seasonal Variation. The effects of seasonality vary depending on the location and the nature of the destination and its attractions (Baum and Hagen 1994). When researching seasonality, many researchers perceive it as a negative phenomenon (Chung 2009, 86). They underscore a variety of issues such as economic and environmental problems and problems arising from seasonal employment (Koenig \& Bischoff 2005, Chung 2009, Cuccia \& Rizzo 2011, Ferrante 2018, Baum, T., Cheung, C. et all. 2016).

The economic effects of seasonality are usually connected with private and social cost. Private cost comprises the cost that is paid by private producers, customers (tourists and residents) and workers. Private producers, such as hotels and restaurants, experience the loss of profit due to under-exploited capacity and fixed cost in the off season while customers pay higher prices in the high season for the product and services offered. The income and quality of life of local residents are therefore very dependent on the periods of high and low seasons. Social costs concern local public utilities putting extreme environmental pressure on the destination. Overcrowding and the rise of prices in the high season affect the everyday quality of life of local residents and can also cause dissatisfaction in tourists

Employment-related issues emerge in both the high season and the low season. Where tourism seasonality is very pronounced, workers usually accept seasonal jobs based on short-term contracts which offer no security for long-term employment. Chung (2009) highlights the lack of demand for off-season jobs and a reduction in employment rates. Therefore, employees will probably leave the destination in order to find more stable employment. As tourism demand changes, the labor market becomes unstable, which ultimately leads to difficulties in maintaining the particular status of a destination (Szivas et al. 2003, Ainsworth \& Purss, 2009). Nevertheless, seasonal work for many workers is seen as an opportunity for additional earnings, especially in the student population.

A company's response to seasonality may vary depending on the nature of the destination's seasonality and on the strategic commitment of the organization. Jolliffe and Farnsworth (2003) consider two possible business strategies: accepting the seasonal nature of the industry or seeking to extend the season and running a non-seasonal business (Figure 1). 
ToSEE - Tourism in Southern and Eastern Europe, Vol. 5, pp. 607-620, 2019

Z. Rahimić, K. Črnjar, V. Čikeš: SEASONAL EMPLOYMENT IN TOURISM ORGANIZATIONS AS A ...

Figure 1: Possible HR and business strategies to manage seasonality in tourism

\begin{tabular}{ll}
$\longrightarrow$ Embrace & Challenge seasonality \\
\hline
\end{tabular}

Source: Jolliffe, L., Farnsworth, R. (2003), "Seasonality in tourism employment: human resource challenges", International Journal of Contemporary Hospitality Management, Vol. 15, Issue: 6, p. 314.

A company will design its business activities depending on the chosen strategy. An enterprise's management, which has adopted the seasonal nature of business as a strategic commitment, may decide not to do business throughout the year or to supplement its income with other off-season activities. Usually, "embracers" are local residents who use tourism as a source of additional income. "Challengers" can be, for example, tour operators seeking to overcome seasonality by looking for new destinations or providing new, innovative services. Their efforts are focused on extending the season, i.e. on designing out-of-season service packages. In order to implement the strategy already formulated, it is necessary to harmonize the policies and practices of human resources management in tourism organizations.

By defining the overall strategy, an enterprise defines its attitude towards the challenges that seasonality brings. This will strongly influence all business activities including the activities comprised in strategic human resource management.

\section{STRATEGIC HUMAN RESOURCE MANAGEMENT AND SEASONALITY IN TOURISM EMPLOYMENT}

Managing people, or their potential, is an extremely complex and demanding task. The most common division of this task is into traditional activities, or activities of a purely administrative nature, and activities that carry a strategic significance to the company. The increasingly turbulent and dynamic business environment related to the establishment and strengthening of the competitive position of the company requires the systematic and careful development of human resources, directed at creating and developing organizational abilities (Torrington 2004, 30-44). The management of human resources is acquiring a new strategic role in the company.

Strategic Human Resource Management refers to the systematic, comprehensive and long-term development of human resources and the use of their potential and talent, knowledge, skills and competencies, and other qualities to achieve strategic differentiation, gain a sustainable competitive advantage, ensure sustainable strategic success, and continually enhance an organization's performance in accordance with its business and strategic goals (Bahtijarević-Šiber 2014, 49). Accordingly, the interrelatedness of strategic management and HRM is becoming a prerequisite for competitive advantages and company success (Figure 2). 
ToSEE - Tourism in Southern and Eastern Europe, Vol. 5, pp. 607-620, 2019 Z. Rahimić, K. Črnjar, V. Čikeš: SEASONAL EMPLOYMENT IN TOURISM ORGANIZATIONS AS A ...

Figure 2: Strategic human resource management

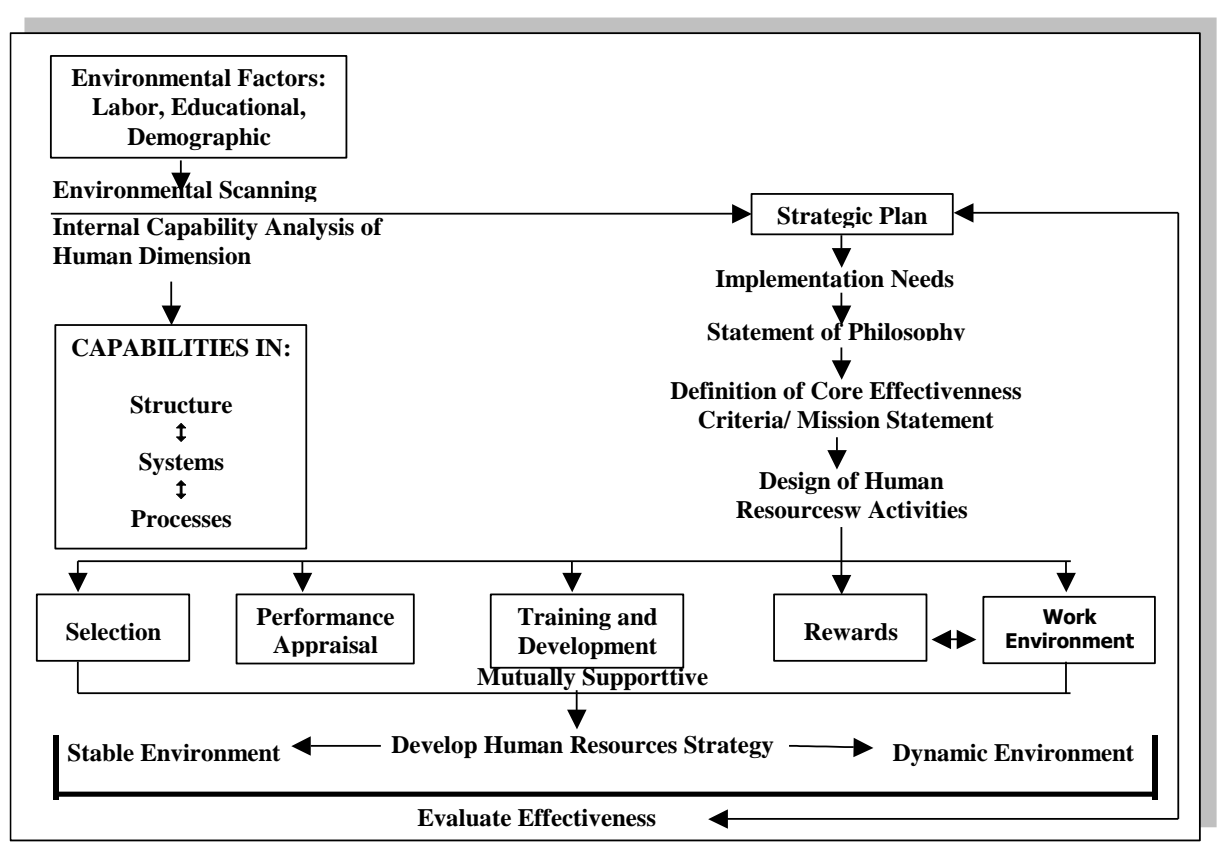

Source: Author's adaptation.

The concept of strategic HRM (Fahtijeravic-Šiber 2014, 62; Butler 1994, 705) has two dimensions of equal importance. The vertical dimension emphasizes the interrelatedness of HRM practices with the process of strategic management (both in the process of designing and in the implementation of the strategy), and the horizontal dimension suggests the need for a high degree of coordination and harmonization of various HRM sub-functions. The model focuses on the necessity of harmonizing the company strategy and HRM activities, and employees' abilities and behavior (providing that they "fit"). A vertical alignment of "fit" refers to human resource management policies being aligned with the strategic orientation of a tourism organization. In the case of tourism organizations, a vertical "fit" means designing human resource management policies depending on whether seasonality is accepted as such or considered as a challenge (embracing seasonality vs challenging seasonality).

It is considered that using the concept of "fit" in the strategic management of human resources of tourism enterprises will achieve the desired behavior and level of service provided by the employees. However, there are also different opinions on that matter. In dynamic environments, where changes are discontinuous and unpredictable, success cannot be expected from fitting the HRM activities to the company strategy, but rather is solely based on the abilities of providing flexible responses and adapting to unpredictable events. Thus, Wright/Snell $(1998,761)$ created a framework that focuses on three points for flexibility: developing HR systems that can be quickly adapted, developing a human capital pool with a wide array of skills, and promoting behavioral flexibility among employees. Accordingly, they propose HRM activities that may 
ToSEE - Tourism in Southern and Eastern Europe, Vol. 5, pp. 607-620, 2019 Z. Rahimić, K. Črnjar, V. Čikeš: SEASONAL EMPLOYMENT IN TOURISM ORGANIZATIONS AS A ...

expand the qualifications and behavior of employees to support various changing or newly emerged strategies.

HRM strategy, practices and activities will differ depending on whether a company embraces seasonality or challenges it. As can be seen in Table 1, the "challenge" of seasonality is a more complex set of actions and measures compared with seasonal business acceptance.

Table 1: HR practice based on the chosen approach of seasonality

\begin{tabular}{|l|l|l|}
\hline HR practice & \multicolumn{1}{|c|}{ Embrace seasonality } & \multicolumn{1}{c|}{ Challenge seasonality } \\
\hline Staffing & $\begin{array}{l}\text { Focus on temporary workers, } \\
\text { retention is not important }\end{array}$ & $\begin{array}{l}\text { Focus on full-time core workers, } \\
\text { supplemented with temporary } \\
\text { workers. } \\
\text { Retention valued }\end{array}$ \\
\hline $\begin{array}{l}\text { Training and } \\
\text { development }\end{array}$ & $\begin{array}{l}\text { Brief orientation and task specific } \\
\text { training }\end{array}$ & $\begin{array}{l}\text { Continual training (including cross } \\
\text { training) }\end{array}$ \\
\hline $\begin{array}{l}\text { Performance } \\
\text { appraisal }\end{array}$ & $\begin{array}{l}\text { Informal appraisal: focus on ability } \\
\text { to perform special tasks }\end{array}$ & $\begin{array}{l}\text { Formal and informal appraisal } \\
\text { techniques: focus on broader-based } \\
\text { competencies and task-specific } \\
\text { abilities. }\end{array}$ \\
\hline Compensation & $\begin{array}{l}\text { Match or lead competitor's base } \\
\text { pay: bonuses based on staying the } \\
\text { entire season }\end{array}$ & $\begin{array}{l}\text { Match competitor's base pay: benefits } \\
\text { and merit to encourage retention: } \\
\text { bonuses for staying beyond the normal } \\
\text { season. }\end{array}$ \\
\hline
\end{tabular}

Source: Jolliffe, L., Farnsworth, R. (2003). "Seasonality in tourism employment: human resource challenges", International Journal of Contemporary Hospitality Management, Vol. 15, No. 6, p. 315

Employment policies and practices should be aligned with the organization's strategic commitment to seasonality vs. challenging seasonality. Tourism organizations are often in situations that require combining the main approaches to seasonality to enable the enterprise to operate more efficiently. As seen in Figure 3, for example, in Front and Back Offices permanent or longer-term employment reduces fluctuation, thus increasing employee satisfaction, which directly affects the quality and productivity of the work and the quality of the service provided and, ultimately, the satisfaction of the clients/guests. In addition to ensuring better financial results, this would enable employees to continuously improve their knowledge, skills and abilities, and would help stop them from leaving the organization and joining the competition. The embracing-seasonality approach could be applied in departments that need far more workers during the peak season. These departments (e.g. Food and Beverages, Housekeeping) tend to hire workers with lower educational levels or with qualifications not related to catering. Staff turnover is higher because the job is temporary and workers are looking for a source of income only for the season. 
ToSEE - Tourism in Southern and Eastern Europe, Vol. 5, pp. 607-620, 2019

Z. Rahimić, K. Črnjar, V. Čikeš: SEASONAL EMPLOYMENT IN TOURISM ORGANIZATIONS AS A ...

Figure 3: Strategic approach of the organization to seasonality and employment

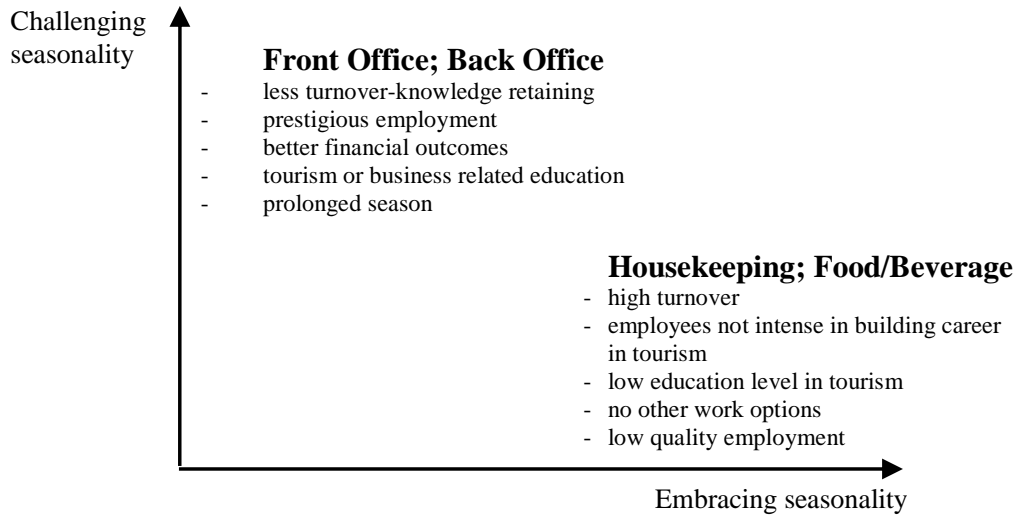

Source: Authors

By combining the two strategic approaches to seasonality in employment, as well as by taking measures and activities to re-engage temporary employees in the next season, tourism organizations can work more effectively and efficiently. Either by extending the season or by re-employing seasonal workers it is possible to overcome negative effects while taking advantage of the positive effects of seasonality in business.

\section{SEASONALITY AND ISSUES IN TOURISM EMPLOYMENT IN THE EU}

The European tourism industry employs over 13 million people. Nearly 8 million of these people work in the food and beverage industry, while the accommodation sector accounts for 2.7 million jobs and travel agencies and tour operators account for just over half a million. The three industries that rely almost entirely on tourism (accommodation, travel agencies/tour operators, air transport) employ 3.6 million people in the EU.

Figure 4: Persons employed by economic activity, EU-28, 2008-2017 (index 2008=100)

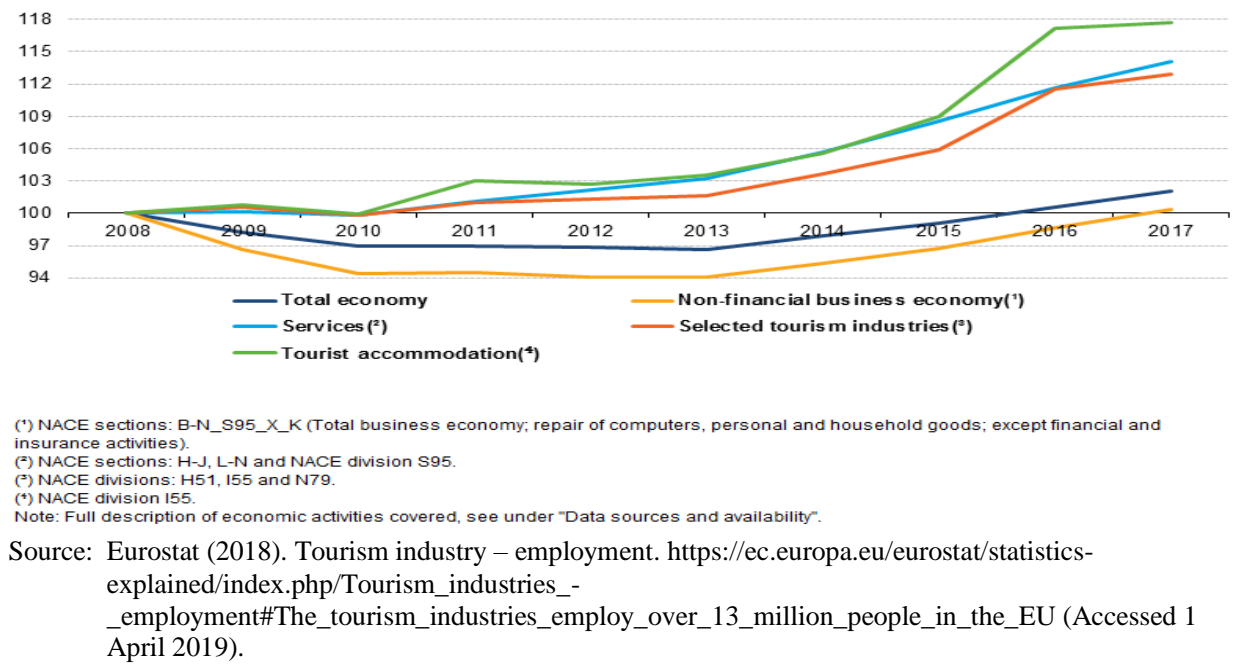


ToSEE - Tourism in Southern and Eastern Europe, Vol. 5, pp. 607-620, 2019

Z. Rahimić, K. Črnjar, V. Čikeš: SEASONAL EMPLOYMENT IN TOURISM ORGANIZATIONS AS A ...

The tourism industry has great potential as a growth sector, even in times of economic turmoil that significantly affects other sectors of the economy. The economic crisis led to a drop in total employment which started recovering in 2014 and reached pre-crisis levels in 2016. The services sector, including the selected core tourism industries, has had an average annual growth rate of $+1.5 \%$ since 2008. More specifically, the tourist accommodation sector has seen an average annual growth of $+1.9 \%$ since 2008 , resulting in a total increase of $+18 \%$ in 2017, compared with 2008 (Figure 4).

Tourism activity can also boost the local economy and labor market. When comparing regional data on tourism intensity (e.g. the annual number of nights spent by tourists per capita of local population) with regional unemployment rates or their deviation from the national average unemployment rate, we see that 21 of the 30 regions with the highest tourism intensity have an unemployment rate below the national average (Figure 5).

Figure 5: Regional unemployment rates compared with the national unemployment rate for NUTS2 regions( $\left.{ }^{1}\right)$ with the highest number of tourism nights per inhabitant, 2017

\begin{tabular}{|c|c|c|c|c|}
\hline Region & $\begin{array}{l}\text { Nights spent(') in } \\
\text { tourist } \\
\text { accommodation }\end{array}$ & Population & $\begin{array}{l}\text { Tourism nights per } \\
\text { inhabitant }\end{array}$ & $\begin{array}{l}\text { Difference between } \\
\text { regional and national } \\
\text { unemployment rate } \\
\text { (in percentage points) }\end{array}$ \\
\hline Notio Aigaio (EL) & 26289568 & 338383 & 78 & -5.5 \\
\hline Ionia Nisia (EL) & 13731722 & 205431 & 67 & -1.9 \\
\hline Provincia Autonoma di Bolzano/Bozen (IT) & 32400662 & 524256 & 62 & -8.1 \\
\hline Illes Balears (ES) & 70697652 & 1150962 & 61 & -4.8 \\
\hline Jadranska Hrvatska (HR) & 81860833 & 1387363 & 59 & -0.3 \\
\hline Algarve (PT) & 22209935 & 441469 & 50 & -1.2 \\
\hline Tirol (AT) & 37356125 & 746153 & 50 & -2.2 \\
\hline Canarias (ES) & 104382580 & 2154978 & 48 & 6.3 \\
\hline Kriti (EL) & 26989449 & 632674 & 43 & -3.8 \\
\hline Salzburg (AT) & 23341866 & 549263 & 42 & -2.4 \\
\hline Corse (FR) & 11035499 & 334283 & 33 & -1.6 \\
\hline Provincia Autonoma di Trento (IT) & 17776030 & 538604 & 33 & -5.5 \\
\hline Região Autónoma da Madeira (PT) & 7951310 & 254876 & 31 & 1.5 \\
\hline Valle d'Aosta/Vallée d'Aoste (IT) & 3599402 & 126883 & 28 & -3.4 \\
\hline Inner London - West (UK)(3) & 32257723 & 1166297 & 28 & 1.3 \\
\hline Zeeland (NL) & 10089457 & 381568 & 26 & -1.9 \\
\hline Cornwall and Isles of Scilly $\left.(\mathrm{UK}){ }^{2}\right)$ & 14140490 & 557858 & 25 & -1.9 \\
\hline Kärnten (AT) & 11310192 & 561077 & 20 & -0.7 \\
\hline
\end{tabular}

Note: The table lists all regions at NUTS2 level reporting more than 20 tourism nights per inhabitant. Analysis not applicable to EE, CY, LV, LT, LU, MT and SI (no NUTS2 regions).

(1) Nights spent in tourist accommodation by non-residents and residents of the Member State. (2) 2016 data

Source: Eurostat (2018). Tourism industry - employment. https://ec.europa.eu/eurostat/statisticsexplained/index.php/Tourism_industries__employment\#The_tourism_industries_employ_over_13_million_people_in_the_EU (Accessed 1 April 2019).

The tourism industry is a major employer of women. Compared with the total nonfinancial business economy, where $36 \%$ of people employed are female, the labor force of the tourism industries includes more female workers $(59 \%)$ than male workers. The highest proportions are seen in accommodation $(61 \%)$, and in travel agencies and tour operators $(64 \%)$. The tourism industries have a particularly young labor force, as these industries can make it easy to enter the job market (13\% of workers aged 15 to 24 compared with $9 \%$ for services or for the non-financial business economy). People with a lower educational level (those who have not finished upper secondary schooling) are equally represented on the labor market as a whole and in the tourism sector (around 
ToSEE - Tourism in Southern and Eastern Europe, Vol. 5, pp. 607-620, 2019

Z. Rahimić, K. Črnjar, V. Čikeš: SEASONAL EMPLOYMENT IN TOURISM ORGANIZATIONS AS A ...

- Nearly one in six people employed in tourism are foreign citizens

- Jobs are less stable in tourism than in the rest of the economy

- Hourly earnings and labor costs in the accommodation sub-sector are below the average for the economy as a whole

Seasonality in tourism activity will result in a high number of seasonal jobs. In most cases, seasonal workers consider this type of engagement as unattractive, temporary employment due to seasonal depletion and the need to seek alternative sources of offseason income. Seasonal work is also perceived as less significant, as less educated, semi-qualified or unqualified workers are most often recruited. This implies poorly paid jobs, which can partly be explained by the qualifying structure of seasonal workers. Murphy (1985), however, considers that seasonality is not necessarily bad for everyone. Some people choose seasonal jobs so they can engage in other activities in the off-season activities or to earn the money needed to fulfill their dreams/wishes (students, artists, housewives...).

The results of work in tourism, as a labor intensive activity, depend in particular on the knowledge, skills, abilities and dedication of the employee's work (Solnet et al. 2015, Hughes \& Rog 2008, Cassel et al. 2018). It is indeed human work that has a dominant role in the service sector. Its importance is emphasized by the term "moment of truth", referring to the immediate interaction between the client and the service-providing organization. Technological changes have significantly affected the way businesses operate and the structure of employees; some jobs have disappeared and other, new ones have emerged. However, changes in the structure of employees ultimately depend on the top management's willingness to implement technological achievements in business and its ability to respond flexibly to changes.

\section{HRM CHALENGES CAUSED BY SEASONAL EMPLOYMENT}

The complexity of tourism and its employment, workforce and labor market characteristics makes defining the processes for the efficient management of employees more difficult than in some other industries. Tourism is a labor-intensive industry with high levels of labor turnover; most jobs have the nature of being unskilled and semiskilled; there is a high proportion of seasonal, part-time and on-call workers; and a high proportion of employees are young people (students) and people with low-level education and skills. The industry has a poor image, relatively low pay, a high proportion of female employees who are generally in the low levels of the occupational structure, poor working conditions and inefficient human resource management practices (Kusluvan et al. 2010, 195).

Strategic human resource management processes, such as recruitment, selection, training, assessment of performance, motivation and career development, will have to be carefully planned and adapted in order to take in account the influence of seasonality in employment, human resources and the labor market. Poor human resource practices in the tourism industry increasingly highlight the challenges that managers have to deal with when striving to efficiently manage human resources in a company. Some of these poor HRM practices in the tourism industry include (Kusluvan et al. 2010) 
ToSEE - Tourism in Southern and Eastern Europe, Vol. 5, pp. 607-620, 2019

Z. Rahimić, K. Črnjar, V. Čikeš: SEASONAL EMPLOYMENT IN TOURISM ORGANIZATIONS AS A ...

unprofessional employee recruitment and selection, limited orientation and training, limited opportunities for career development and promotion, low pay and benefits, absence of overtime pay, absence of employee empowerment and participation, low job security and stability, limited career management and prospects, and no or unprofessional employee performance appraisal.

The main issues that employers working in organizations characterized by seasonal employment will have to address as a part of their human resource strategy are directly connected with the problems of attracting employees to work in the industry, developing employees to possess the competencies needed to ensure high-quality service and retaining them in the face of seasonal employment. The question is how human resource management activities can contribute to the success of tourism organizations and their image of an attractive employer, taking into account the actual and potential effects of seasonality.

\section{Figure 7: HRM processes framework in seasonal employment in tourism}

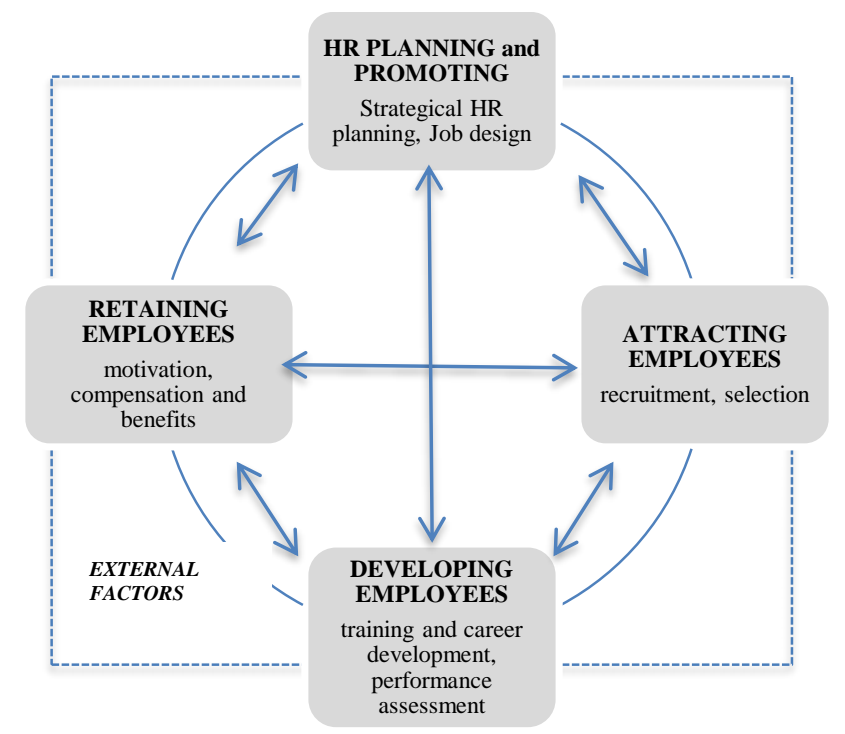

Source: Authors.

Attracting, developing and retaining employees are the major challenges managers face when the labor market and the industry are strongly affected by seasonality (Figure 7). Seasonality, irregular working conditions, shortage of personnel, under-qualified employees and noncompetitive wages compared with other industries make jobs in tourism less attractive, thus posing a challenge for organizations and intensely influencing processes such as recruitment, retention and development.

In overcoming recruitment challenges, digital technology will play a key role in promoting the industry and attracting talent. Companies are designing new recruitment strategies, launching original recruitment campaigns using mobile apps, social networks and collaborative software, and implementing tools to make hiring easier (recruitment 
ToSEE - Tourism in Southern and Eastern Europe, Vol. 5, pp. 607-620, 2019

Z. Rahimić, K. Črnjar, V. Čikeš: SEASONAL EMPLOYMENT IN TOURISM ORGANIZATIONS AS A ...

videos, AI and digital platforms etc.). The main aim of a retention strategy will be to stabilize seasonal employment, increase employee recognition, offer internal promotion, improve new employee integration, provide training to achieve a multi-skilled workforce and develop mentorship programs.

Recruiting and selecting seasonal workers and then teaching them the job are significant challenges to human resource management. Because the recruitment, training and engagement of seasonal workers before the start of each season is costly, organizations in the tourism sector are recommended to try to employ the same workers already trained in previous years and thereby reducing costs and ensuring greater quality for the end consumer. Potential employees should be offered year-round work with two different seasonal businesses whose activities are complementary. By helping seasonal workers find jobs in other businesses in the off-season, the employer is increasing the likelihood the employees will return to work next season. Workers have the benefit of returning to the same seasonal job where they know the environment and job requirements, reducing stress to a minimum and giving them a sense of security. Therefore, the retention of seasonal workers is beneficial for both employees and employers.

\section{CONCLUSION}

High seasonality in tourism activities is reflected in tourism employment. Regions with a higher level of tourism activities tend to have a lower unemployment rate. Tourism creates jobs for women and attracts young people, foreign citizens and workers with lower educational levels but the jobs are less stable and earnings are below the average of the economy. The conclusions reached in this paper by analyzing the recent statistics on employment in the EU tourism industry are consistent with those of other researchers whose work has focused on defining the key characteristics of employment, the workforce and the labor market in the tourism and hospitality industry.

Seasonal employment in tourism impacts HRM policies and the HR strategy in general. Companies should formulate their strategies based on whether they choose to embrace seasonality or challenge it. They should then align their HR practices and policies with the chosen strategy. The challenges for managing human resources in tourism are reflected primarily in the recruitment, retention and development of employees who need to have adequate knowledge and competencies to be able to deliver high-quality service. Employers should strive to respond to the challenges of seasonality by proposing solutions aimed at ensuring more efficient and effective seasonal employment in tourism.

\section{ACKNOWLEDGEMENT}

This paper has been financially supported by the University of Rijeka, for the project ZP UNIRI 2/17. 
ToSEE - Tourism in Southern and Eastern Europe, Vol. 5, pp. 607-620, 2019

Z. Rahimić, K. Črnjar, V. Čikeš: SEASONAL EMPLOYMENT IN TOURISM ORGANIZATIONS AS A ...

\section{REFERENCES}

Ainsworth, S., Purss, A. (2009), "Same time, next year? Human resource management and seasonal workers", Personnel Review, Vol. 38, No. 3, pp. 217-235.

Bahtijarević-Šiber, F. (1999), Menadžment ljudskih potencijal, Golden marketing, Zagreb.

Bahtijarević-Šiber, F. (2014), Strateški menadžment ljudskih potencijala - Suvremeni trendovi i izazovi, Školska knjiga, Zagreb.

Baron, R.R.V. (1976), Seasonality in Tourism: A Guide to the Analysis of Seasonality and Trends for Policy Making, Economist Intelligence Unit, London.

Baum, T., Cheung, C. et all. (2016), "Sustainability and the Tourism and Hospitality Workforce: A Thematic Analysis", Sustainability, Vol. 8, pp. 809, https://doi.org/10.3390/su8080809

Baum, T., Hagan, L. (1997), "Responses to seasonality in tourism: the experience of peripheral destinations", International Tourism Research Conference on Peripheral Area Tourism, Research Centre of Bornholm, Denmark, pp. 8.

Baum, T., Hagen, L. (1999), "Responses to Seasonality: the experiences of peripheral destinations", International Journal of Tourism Research, Vol. 1, No. 5, pp. 299-312.

Baum, T., Lundtrop, S. (2001), Seasonality in Tourism, Elsevier Science Ltd, Oxford.

Butler, R.W. (2001), "Seasonality in tourism: issues and implications", in Baum, T. \& S. Lundtorp, S. (Eds.), Seasonality in tourism, Elsevier Science, Oxford, pp. 5-22.

Cassel, S.H., Thulemark, M., Duncan, T. (2018), "Career paths and mobility in the Swedish hospitality sector", Tourism Geographies, Vol. 20, No. 1, pp. 29-48, doi: 10.1080/14616688.2017.1402946

Chung, J.Y. (2009), "Seasonality in tourism: a review", e-Review of Tourism Research (eRTR), Vol. 7, No. 5, pp. 86.

Cisneros-Martínez, J. D., McCabe, S., Fernández-Morales, A. (2018), "The contribution of social tourism to sustainable tourism: a case study of seasonally adjusted programmes in Spain", Journal of Sustainable Tourism, Vol. 26, No. 1, pp. 85-107.

Cuccia, T., Rizzo, I. (2011), "Tourism seasonality in cultural destinations: Empirical evidence from Sicily", Tourism management, Vol. 32, pp. 589-592, https://doi.org/10.1016/j.tourman.2010.05.008

Duncan, T, Scott, D.G., Baum, T (2013), "The mobilities of hospitality work: an exploration of issues and debates", Annals of Tourism Research, Vol. 41, pp. 1-19.

Eurostat (2018), Tourism industry - employment. https://ec.europa.eu/eurostat/statisticsexplained/index.php/Tourism_industries__employment\#The_tourism_industries_employ_over_13_million_people_in_the_EU (Accessed 1 April 2019).

Ferrante, M., Lo Magno, G.L., De Cantis, S. (2018), "Measuring tourism seasonality across European countries", Tourism Management, Vol. 68, pp. 220-235, doi:10.1016/j.tourman.2018.03.015

Hughes, J.C., Rog, E. (2008), "Talent management", International Journal of Contemporary Hospitality Management, Vol. 20, No. 7, pp. 743-757.

Jolliffe, L., Farnsworth, R. (2003), "Seasonality of tourism employment: human resources challenges", International Journal of Contemporary Hospitality, Vol. 15, No. 6, pp. 312-317.

Koenig-Lewis, N., Bischoff, E.E. (2005), "Seasonality research: the state of the art", International Journal of. Tourism Research, Vol. 7, pp. 201-219, doi:10.1002/jtr.531

Koryun, A. (2015), "Characteristics of Human Resources Management in Tourism Industry of Republic of Armenia", International Conference on Business, Marketing \& Informations System Management (BMISM 15), Nov. 25-26, 2015 Paris, France, http://dx.doi.org/10.15242/ICEHM.ED1115001

Kusluvan, S., Kusluvan, Z., Ilhan, I., Buyruk, L. (2010), "The Human Dimension: A Review of Human Resources Management Issues in the Tourism and Hospitality Industry", Cornell Hospitality Quarterly, Vol. 51, No. 2, pp. 171-214, https://doi.org/10.1177/1938965510362871

Morse, S.C., Smith, E.M. (2015), "Employment Impacts of Off-Peak Seasonal Tourism Development", Business and Economics Journal, Vol. 6, No. 2, doi:10.4172/2151-6219.1000150

Oxford Economics (2015), The economic contribution of the UK Hospitality Industry. http://www.bha.org.uk/wordpress/wp-content/uploads/2015/09/Economic-contribution-of-theUK-hospitality-industry.pdf (Accessed 4 April 2019).

Shani, A., Uriely, N., Reichel, A., Ginsburg, L. (2014), "Emotional labor in the hospitality industry: The influence of contextual factors", International Journal of Hospitality Management, Vol. 37, pp. $150-158$.

Solnet, D., Kralj, A., Baum, T. (2015), “360 Degrees of Pressure: The Changing Role of the HR Professional in the Hospitality Industry", Journal of Hospitality \& Tourism Research, Vol. 39, No. 2, pp. 271292. doi: 10.1177/1096348012471380. 
ToSEE - Tourism in Southern and Eastern Europe, Vol. 5, pp. 607-620, 2019

Z. Rahimić, K. Črnjar, V. Čikeš: SEASONAL EMPLOYMENT IN TOURISM ORGANIZATIONS AS A ...

Szivas, E., Riley, M., Airey, D. (2003), “Labour mobility into tourism. Attraction and Satisfaction”, Annals of Tourism Research, Vol. 30, No. 1, pp. 64-75.

Torrington, D., Hall, L. (2004), Menadžment ljudskih resursa, Data status, Beograd.

Tracey, B. (2014), "A review of human resources management research", International Journal of Contemporary Hospitality Management, Vol. 26, No. 5, pp. 679-705.

Wright, P.M., Snell, S.A. (1998), "Toward a Unifying Framework for Exploring Fit and Flexibility in Strategic Human Resource Management”, Academy of Management Review, Vol. 2, No. 4, pp. 756-772.

Zijada Rahimić, PhD, Full Professor

University of Sarajevo

School of Economics and Business

Trg oslobođenja - Alija Izetbegović 1, 71000 Sarajevo, Bosnia and Herzegovina

Contact phone number: +38733275998

E-mail: zijada.rahimic@efsa.unsa.ba

Kristina Črnjar, $\mathrm{PhD}$, Associate Professor

University of Rijeka

Faculty of Tourism and Hospitality Management

Primorska 42, 51410 Opatija, Croatia

Contact phone number: +385 51294185

E-mail: kcrnjar@fthm.hr

Vedrana Čikeš, PhD Student, Assistant

University of Rijeka

Faculty of Tourism and Hospitality Management

Primorska 42, 51410 Opatija, Croatia

Contact phone number: +385 51294715

E-mail: vedrana.cikes@fthm.hr 